\title{
In Vitro and in Vivo Infection of Rhesus Monkey Microglial Cells by Simian Immunodeficiency Virus
}

\author{
R. BRINKMANN, ${ }^{*}$ A. SCHWINN, $\dagger$ J. MÜLLER, $\neq C$. STAHL-HENNIG,,$C$. COULIBALY, $\S$ \\ G. HUNSMANN,§ S. CZUB, $\neq$ A. RETHWILM, ${ }^{*}$ R. DÖRRIES, ${ }^{*}$ AND V. TER MEULEN ${ }^{*, 1}$ \\ "Institut fur Virologie und Immunbiologie. Würzburg, Germany; ¥Institut für Pathologie, Würzburg, Germany; §Deutsches Primatenzentrum \\ GmbH, Gottingen, Germany; and +Dermatologische Universitatsklinik, Würzburg, Germany
}

Received December 18, 1992; accepted April 21, 1993

\begin{abstract}
The observation that microglial cells in brain tissue are probably a major target for human immunodeficiency virus (HIV infection has raised interest in the pathogenic role of this cell population for the development of neuro-AIDS. Since it is very difficult to obtain microglia from normal or diseased human brain we studied microglial cells isolated from fresh brain tissue of uninfected and simian immunodeficiency virus (SIV) infected rhesus monkeys (Macacca mulatta) in comparison to peripheral blood macrophages. Besides the characterization of the phenotypes of these two cell populations, we examined the replication of SIV in the cells in addition to the effect of viral infection on the expression of cell surface molecules. We found that microglia and macrophages support replication of the wild-type SIV $_{\text {mac231 }}$ strain as well as the infectious clone $\left(S V_{239}\right)$. Infectious virus was produced and a CPE developed. Isolated microglial cells from SIV-infected monkeys were latently infected independent of the presence of neuropathological lesions and produced infectious virus after 20-25 days in culture. In situ hybridization revealed that only a smal percentage of isolated microglial cells are productively infected in vivo, yet the majority of these expressed MHC class II molecules. This indicated a state of activation that is acquired in vivo. These findings indicate that microglia are a prime target cell for SIV infection in CNS tissue. 1993 Academic Prass, inc.
\end{abstract}

\section{INTRODUCTION}

The development of neuro-AIDS is of great clinical importance and has been linked to human immunodeficiency virus (HIV) infection of brain tissue. Spread of virus through brain tissue is associated with inflammatory and degenerative neuropathological changes which lead to a variety of neurological deficits. However, despite a large amount of evidence that HIV is present in the nervous system, the underlying pathogenic mechanism leading to CNS changes is still unknown. Virus has been mainly found in multi- and mononucleated cells expressing monocyte/macrophage lineage markers and to a lesser extent in astrocytes, oligodendrocytes and endothelial cells Wiley et al., 1986: Vazeux et al., 1987; Stoler et al., 1986; Gyorkey et al., 1987). However, the size of lesions in relation to the few cells expressing virus proteins suggests that the brain lesions are not directly caused by cytopathic effects as a result of virus replication in infected cells. but rather indirectly by HIV-specific products or aberrantly secreted cellular products interfering with nervous system function (Tillman and Wigdahl, 1991). In this context, microglial cells which derive from bone

\footnotetext{
1 To whom reprint requests should be addressed at Institut for Virologie und Immunbiologie, Versbacher Str.7, 8700 Wurzburg. Germany.
}

marrow precursor cells and are closely related to peripheral macrophages are important target cells for HIV. Therefore, the characterization of HIV interaction with microglial cells in brain tissue and in tissue culture may lead to a better understanding of the pathogenesis of neuro-AIDS.

Studies of HIV infection in microglial cells are hampered by the fact that isolation of these cells from either AIDS brain or normal brain tissue has been difficult to achieve due to the problem of obtaining well preserved brain material soon after death. Moreover, isolation of microglia from brain tissue, in particular from adult brain, has been technically difficult since microglial cells differentiate morphologically in relation to the tissue environment in which they reside. Therefore, the majority of in vitro studies have been performed with microglial cells from fetal or neonatal brain tissue of rodents (Dickson et al., 1991). Although the problem of isolating microglial cells from adult brain has recently been overcome (Sedgwick et al., 1991), this procedure requires a large portion of brain tissue which brain biopsies alone cannot provide (Sedgwick et al., 1991). Therefore, we decided to study the infection of simian immunodeficiency virus (SIV) in the rhesus monkey (Macacca mulatta) model since it has been shown that SIV causes an immunodeficiency syndrome in this animal species with involvement of the CNS which is quite similar to human AIDS (Letvin and King, 1990; Kestler 
et al., 1990; Lackner et al., 1991). Here we report on the isolation and phenotypic characterization of microglial cells from both uninfected and SIV-infected rhesus monkeys and compared the replication of SIV in these cells to peripheral macrophages.

\section{MATERIAL AND METHODS}

Isolation of microglia from fresh brain

Perfused CNS tissue were derived from non-infected and in vivo SIV $\mathrm{Sac25}_{\text {1 }}$-infected rhesus monkeys (M. mulatta). Microglia were isolated directly from fresh tissue using a Percoll gradient technique (Sedgwick et al., 1991; Brinkmann et al., 1992). Briefly, following removal of the meninges, $50 \mathrm{~g}$ of brain tissue was transferred into cold Hank's solution $\left(4^{\circ}\right)$ buffered with $2 \%$ FCS (HBSS), minced, and forced through a 100-mesh metal sieve with the plunger of a $20-\mathrm{ml}$ plastic syringe. The dissociated material was collected by centrifugation at $170 \mathrm{~g}$, for $10 \mathrm{~min}$ at $4^{\circ}$ in a 50 -mi plastic centrifuge tube. The resulting pellet was resuspended in a DNase/collagenase buffer containing $500 \mathrm{U}$ collagenase (Sigma, Deisenhofen, Germany) and $400 \mathrm{U}$ DNase I (Boehringer-Mannheim, Germany)/g of tissue in HBSS and digested enzymatically for $60 \mathrm{~min}$ at $37^{\circ}$ in a rocking water bath. The digested homogenate was pelleted and resuspended in HBSS. The suspension $(79 \mathrm{ml})$ was mixed with isotonic Percoll $(21 \mathrm{ml}) \mathrm{pH} 7.4$ at $1.124 \mathrm{~g} / \mathrm{ml}$ (Biochrom, Berlin, Germany) resulting in a density of $1.030 \mathrm{~g} / \mathrm{ml}$. This was layered onto $5 \mathrm{ml}$ of isotonic Percoll at $1.088 \mathrm{~g} / \mathrm{ml}$ in a $50 \mathrm{ml}$ centrifuge tube. The tube was then centrifuged at $1250 \mathrm{~g}$ for 15 min at $20^{\circ}$ (acceleration within $1 \mathrm{~min}$ and deceleration without brake). Cells were collected from the 1.088 interface, washed with HBSS, and resuspended in $5 \mathrm{ml}$ HBSS. This cell suspension was layered onto of a second Percoll density gradient, composed of four density steps at $1.124,1.088,1.077,1.050$, and $1.030 \mathrm{~g} / \mathrm{ml}$ from the bottom of the tube $(10 \mathrm{ml}$ vol). The gradient was centrifuged at $1250 \mathrm{~g}$ for $15 \mathrm{~min}$ at $20^{\circ}$. Cells were collected from the 1.050 interface, washed in HBSS, and resuspended in RPMI 1640 medium supplemented with $10 \%$ human $\mathrm{AB}^{+}$serum, Refobacin $(50$ $\mathrm{U} / \mathrm{ml}$ ) and granulocyte-macrophage colony stimulating factor (GM-CSF) purchased from Boehringer at a concentration of $10^{5}$ cells $/ \mathrm{ml}$. These cells were seeded in 6-well-cluster plates and cultured at $37^{\circ}$ with $5 \%$ $\mathrm{CO}_{2}$. Cultures were used for experiments 10 days after plating.

\section{Macrophage culture}

Macrophages were derived from the peripheral blood of normal and SIV $_{\text {mac25, }}$-infected rhesus monkeys ( $M$. mulatta). Leukocytes were purified from heparinized peripheral blood (PBL) by centrifugation through
Ficoll-Hypaque gradients and adherent cell cultures were established in the same medium and density as the microglia.

\section{Source of antibodies and staining procedures}

Monoclonal antibodies (mAbs) specific for human CD4 (T helper cells), CD11b (CR3 complement receptor), CD14 (monocytes, MQ), CD45 (leukocyte common antigen), and MHC class II (HLA-DR L243) were purchased from Becton-Dickinson (Heidelberg, Germany). Anti-CD11a (lymphocyte function antigen), CD16 (FC- $\gamma$-RIII), CD29 ( $\beta$-1 integrin), CD54 (ICAM-1), and CD58 (LFA-3) were ordered from Dianova (Hamburg, Germany). Anti-CD32 (Fc- $\gamma$-RII) and CD64 (Fc- $\gamma$ RI) were obtained from Medarex Inc. (West Lebanon, $\mathrm{NH})$. Anti-MHC class I mAb was purchased from Serotec (Oxford, UK). Monoclonal anti-S100 and polyclonal anti-GFAP antibodies were purchased from DAKO (Hamburg, Germany). Monoclonal anti-endothelial cell antibody was purchased from Biochrom/Monosan (Berlin, Germany). Anti- $\alpha$-actin (ASM-1) antibody was obtained from Progen (Heidelberg, Germany). Monoclonal antibody directed against galactocerebroside, a surface antigen on oligodendrocytes and Schwann cells, was a generous gift from Dr. B. Ranscht, MaxPlanck-Gesellschaft, Tübingen. Monoclonal anti-SIV p27 core protein antibody was provided by the AIDS Research and Reference Reagent Program, DIL-acLDL by Paesel and Lorei, Frankfurt, Germany.

CD4, CD11a, CD11b, CD14, CD16, CD29, CD32, CD45, CD54, CD58, CD64, CD68, MHC class I (HLA $A B C$ ), and MHC class $\|$ (HLA-DR) are all cell surface antigens. Staining was performed on unfixed cells at $4^{\circ}$ in LAB TAK chamber slides (Miles Scientific, Naperville, IL) in which microglia and macrophages had been seeded. For control staining a mouse IgG (Dianova) was used. Medium was removed and the first antibody was added for $30 \mathrm{~min}$, followed by three wash steps with $\mathrm{Ca} / \mathrm{Mg}$ free PBS containing $0.4 \% \mathrm{BSA}$. Staining was visualized by a second FITC-goat F(ab) antimouse $\lg \mathrm{G}(\mathrm{H}+\mathrm{L}$ ) antibody (Zymed Lab Inc., Conco Lab Div., Wiesbaden, Germany). S100, GFAP, and p27 core protein were stained intracellularly. First, cells were fixed with $3.5 \%$ formaldehyde for $30 \mathrm{~min}$, incubated with $0.25 \%$ Triton-X-100 for $15 \mathrm{~min}$, and blocked with $\mathrm{Ca} / \mathrm{Mg}$ free PBS containing $0.4 \%$ BSA for further $15 \mathrm{~min}$. The first antibody was added and incubated for $1 \mathrm{hr}$ at room temperature. After three washes for $5 \mathrm{~min}$ each, the second antibody was added (FITC-goat F(ab') anti-mouse $\operatorname{lgG}(H+L)$ for p24 and FITC-goat F(ab') anti-rabbit $\lg G(H+L)$ for $S 100$ and GFAP). Low density lipoprotein staining with DIL-ac-LDL was carried out as described elsewhere (Giulian and Baker, 1986). Recombined human interferon- $\gamma$ for inducing $\mathrm{MHC}$ class II expression on microglial cells was a generous gift 
from Dr. G. R. Adolf, Ernst Boeringer Institut für Arzneimittelforschung. Wien, Austria.

\section{Virus and infectivity assays}

For in vitro infection the virus strains $\operatorname{SIV}_{\operatorname{mac25}}$ and

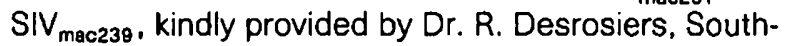
borough, Massachusetts, were used. Stock virus was prepared on human T-cell lines and cultures were inoculated at an m.o.i. of 1 which corresponded to $43 \mathrm{ng}$ p27 gag antigen for strain 251 and $26 \mathrm{ng} \mathrm{p27} \mathrm{for} \mathrm{strain}$ 239 , respectively. Monkeys were infected with the virus-strain SIV mac251 $32 \mathrm{H}$ (kindly provided by Dr. $M$. Cranage, Salisbury, England).

Infectivity determination of supernatants from infected microglia and macrophage cultures was performed on human peripheral blood lymphocytes (PBL) from healthy donors following depletion of CD8 cells from the population. The remaining cells were seeded in 24-well cluster plates using $1 \times 10^{4}$ cells (per well). After 2 days stimulation of PBL's with $0.1 \%$ PHA-P (Pharmacia, Uppsala, Sweden) aliquots of diluted supernatants from infected cultures were added. The PBL-medium comprised RPMI supplemented with $10 \%$ FCS, $2 \mathrm{mM}$ glutamine (Seromed/Biochrom, Berlin, Germany), $10 \mathrm{U} / \mathrm{ml}$ anti $\alpha$-interferon (Boehringer), and $1 \mu \mathrm{g} / \mathrm{ml}$ Polybrene (Sigma, Deisenhofen, Germany). Wells were examined for a period of 10 days for CPE. The virus titer was calculated as the dilution of the virus required to infect $50 \%$ of the cultures (TCID50).

For analyzing p27 core protein in culture supernatants the SIV core antigen assay (Coulter Corp., Luton, England) was used.

\section{In situ hybridization}

In situ hybridization studies, for the detection of SIV viral nucleic acid in microglia and macrophages, were performed on tissue culture swaps fixed in acetone and post fixed in $5 \%$ fresh paraformaldehyde, essentially as previously described (Mori et al., 1990). Antisense RNA to the SIV gag gene was transcribed in vitro using the bacteriophage SP6 promotor of the plasmid pGem-4 and incorporating ${ }^{35} \mathrm{~S}$-UTP. Slides were developed after exposure to the photographic emulsion (IIford K2, UK) for 1 to 2 weeks. Sense RNA and irrelevant anti-sense probes (measles, wild mouse virus) were used as negative controls.

\section{RESULTS}

\section{Phenotypic characterization of isolated microglial cells}

The isolation of microglia from 2- to 3-year-old thesus monkeys yielded cells which were morphologically similar to amoeboid microglia with a plump cytoplasm
TABLE 1

Characterization of Cell Surface and Intracellular Molecules of Rhesus Monkey Peripheral Macrophages and Microglaal CelLS

\begin{tabular}{|c|c|c|c|c|}
\hline $\begin{array}{c}C D \\
\text { classification }\end{array}$ & $\begin{array}{l}\text { Recognized } \\
\text { cells }\end{array}$ & $\begin{array}{l}\text { Recognized } \\
\text { protein }\end{array}$ & Macrophages & $\begin{array}{l}\text { Microglial } \\
\text { cells }\end{array}$ \\
\hline $\mathrm{CD} 4$ & $T$ sub & $C D 4$ & + & + \\
\hline $\operatorname{CD} 110^{\circ}$ & Leucocytes & $\begin{array}{l}\text { LFA-1 } \\
\text { 8-chain }\end{array}$ & +++ & +++ \\
\hline CD11 $b^{\circ}$ & M. G. PIt & $\begin{array}{l}\text { CR3 } \\
\text { a-chain }\end{array}$ & $\begin{array}{l}+++ \\
100 \%\end{array}$ & $\begin{array}{l}++++ \\
100 \%\end{array}$ \\
\hline $\operatorname{CD~} 14^{\circ}$ & M. (G), LHC & 9055 & $\begin{array}{c}+++ \\
100 \%\end{array}$ & $\begin{array}{c}+ \\
25 \%\end{array}$ \\
\hline $\operatorname{CD} 16^{\circ}$ & $N K, G, M Q$ & FC-g-RIII & + & + \\
\hline CD 18 & Leucocytes & $\begin{array}{l}\text { CDII } \\
\text { b-chain }\end{array}$ & +++ & +++ \\
\hline $\operatorname{CD} 29^{\circ}$ & Most cells & $\begin{array}{l}\text { VLA } \\
\text { b-chain } \\
\text { integrin b1 }\end{array}$ & +++ & +++ \\
\hline CD $32^{\circ}$ & $M, G, B$ & Fc-g-RIII & $++t$ & t+t \\
\hline CD45 RA* & $\begin{array}{l}T \text { sub, B, G, } \\
M\end{array}$ & $\begin{array}{c}\text { restricted } \\
\text { T200 }\end{array}$ & ++ & + \\
\hline $\operatorname{CD} 54^{\circ}$ & act. cells & ICAM-1 & + & + \\
\hline $\operatorname{CD} 58^{\circ}$ & $\begin{array}{l}\text { Leucocytes. } \\
\text { epithel }\end{array}$ & LFA-3 & + & + \\
\hline $\operatorname{Co~} 64^{\circ}$ & Plt active, M & Fc-g-RI & ++ & $++t$ \\
\hline \multirow[t]{8}{*}{$\operatorname{CD} 68^{\circ}$} & MO & gpt 10 & ++ & ++ \\
\hline & Most cells & MHC CLI" & +++ & +++ \\
\hline & APC & MHC CL H० & $+t+$ & \pm \\
\hline & $M, M O$ & LDL & $++t$ & +++ \\
\hline & $A$ & GFAPO & - & - \\
\hline & A & $S 100^{\circ}$ & - & - \\
\hline & 0 & Galce & - & - \\
\hline & $F$ & a-Actin ${ }^{\circ}$ & - & - \\
\hline
\end{tabular}

- Surface staining: ${ }^{b}$ intracellular staining.

Note. Abbreviations used: $A$, astrocytes; APC, antigen presenting cell; B, B-cells; F, fibroblasts; G, granulocytes; GalC, galactocerebroside; GFAP, glial fibrillary acidic protein; ICAM, Intercellular adhesion molecule; LDL, low density lipoprotein receptor: LFA. lymphocyte function antigen; $L H C$, Langerhans cells; $M$, monocytes; $M H C$, main histocompatibility complex; MQ. macrophages; NK, natural killer cells; $O$, oligodendrocytes; PIt, platelets; T, T-cells; VLA, very late entigens. Fluorescent intensity: (-) neg; $1+$, weak; $2+$, medium; $3+$. strong. If not indicated otherwise. $100 \%$ of the cells were positive.

and the occasional cell processes (Dickson et al., 1991). In culture these cells did not divide and could be kept alive for a period of up to 30-35 days. In comparison to peripheral macrophages, microglial cells are larger, rounded, and contain more lipid material than macrophages. Staining of surface antigens on 8 - to 12-day-old cultures revealed a similar staining pattern to that for peripheral macrophages (Table 1). Microglia in culture expressed, to almost the same extent, all macrophage markers and could not be distinguished on this basis from peripheral macrophages. The only exception seems to be the CD14 and MHC class II molecules. MHC class II molecules were detectable on very few microglial cells following isolation with weak staining for CD14 on only $25 \%$ of these cells. However, the CD14 negative cells were not contaminants with other brain cells since staining for GFAP, 
S100 or galactocerebroside were negative. Only occasionally were fibroblasts seen which gave positive staining for $\alpha$-actin.

\section{Infection of microglial cells and peripheral macrophages with SIV}

Six days after isolation of microglia, cells were infected either with SIV mac25, $_{\text {, }}$ or with the virus derived from the infectious molecular clone SIV mac239 at an m.o.i. of 1. The cultures were monitored for both infectious virus and $p 27$ release into the supernatant in addition to the determination of the percentage of infected cells and development of CPE (Fig. 1). As controls, peripheral macrophages were used. As shown in

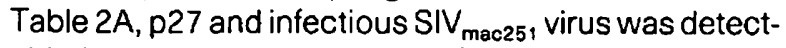
able in macrophages 7 days after infection, whereas infected microglia started to shed p27 by day 3 (Table $2 B)$. With the detection of p27, CPE began to develop (Tables $2 \mathrm{~A}$ and $2 \mathrm{~B}$ ). The maximum titer of infectious virus released into the supernatant occurred at 9 to 11 days post-infection for microglia and macrophages, respectively. With time, the degree of CPE increased whereas the titer for $\mathrm{p} 27$ and infectious virus dropped and became absent after 21 days. At that time the majority of infected cells had aggregated and formed giant cells as shown in Fig. 1B. In addition, non-fused infected microglial cells were seen with large vacuoles. However, whereas all macrophages were infected by day 15 , only $20 \%$ of the microglial cells were infectable with the remainder resisting infection and also cell fusion (Table 2B). Compared to the wild-type virus, the replication of molecularly cloned SIV mac239 in macrophages and microglia was delayed by approximately 4-6 days (Tables $2 \mathrm{C}$ and 2D). This virus produced also approximately 10 times less infectious virus and gave rise to slightly reduced levels of gag antigen in microglial cells compared to SIV $_{\text {mac251 }}$ infection although the extent of CPE and the number of productively infected cells were the same.

Since it has been shown that cytokines may alter the production of HIV 1 in primary mononuclear phagocytes (Koyanagi et al., 1988), microglial cells were kept beside GM-CSF also in the presence of $11-1$, and II-3. However, none of these cytokines changed significantly either the virus replication kinetics or virus yield.

\section{The effect of SIV-infection on the expression of surface molecules on microglial cells}

It was of interest to discover whether SIV $_{\text {mac251 }}$ infection of microglial cells leads to cell surface changes as a consequence of viral replication. Therefore, microglia and macrophage cultures infected for 15 days were stained with the library of antibodies listed in Table 1. In none of these cultures were significant changes observed in comparison to uninfected control cells, ex-

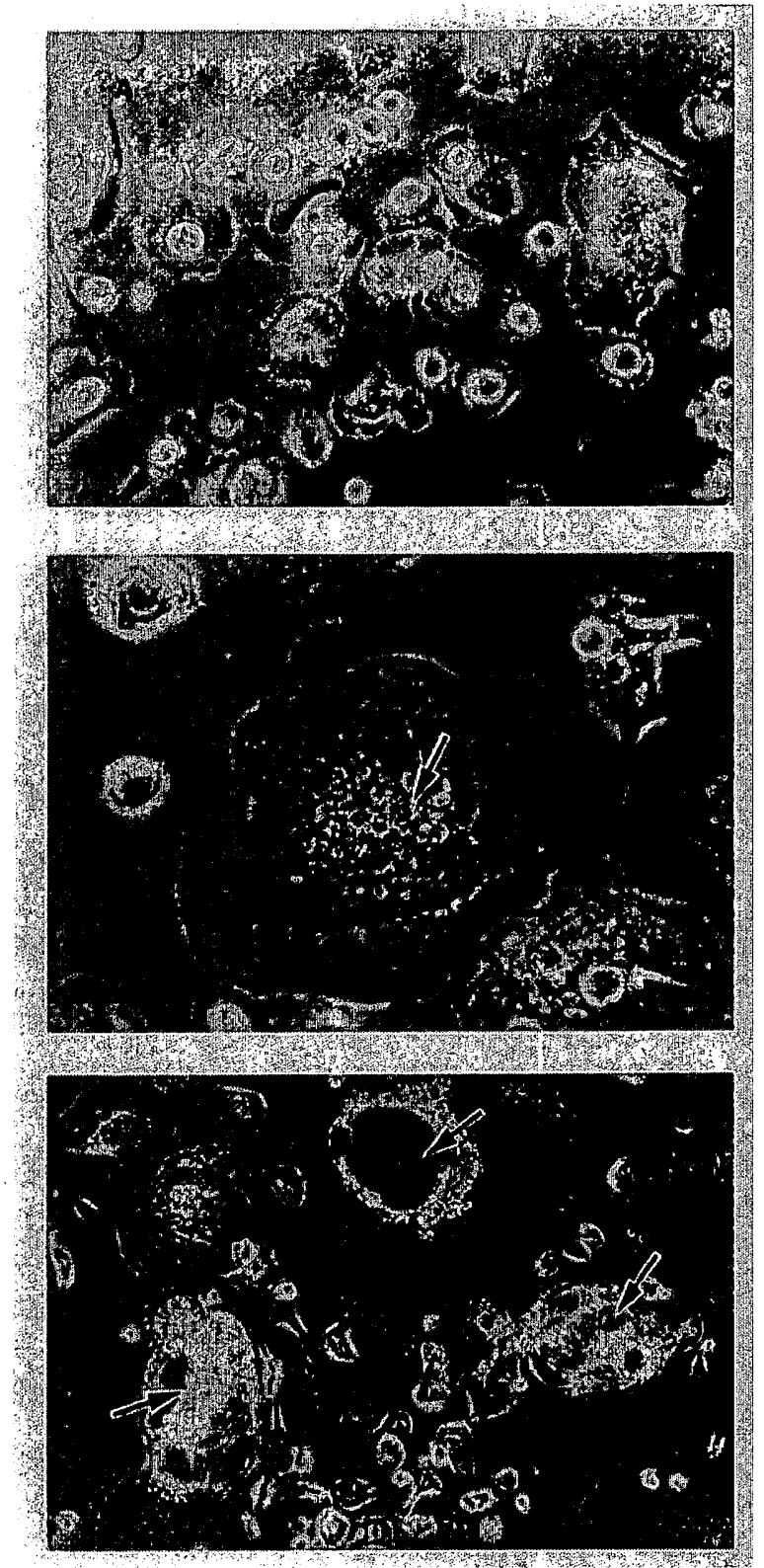

Fig. 1. Light microscopic characteristics of microglia isolated from rhesus monkeys. (A) uninfected cells with typical ameboid morphology. (B + C) SIV mac251 -infected microglial cells 15 days p.i.; (B) Multinucleated giant cell (arrow). (C) Microglial cells strongly vacuolized (arrows). Magnification $\times 80$.

cept for CD14 and MHC class II molecules. Whereas only 20-25\% of uninfected microglial cells expressed CD14 molecules on the cell membrane, infection led to $100 \%$ expression of this surface structure in microglia despite of the fact that only $20 \%$ of these cells became productively infected. Similar observations were made for MHC class II. Microglial cells isolated from uninfected rhesus monkeys were either completely negative or occasionally weakly positive, but in vitro infection was accompanied, within 4 days, by a MHC class 
TABLE 2

Infection of Macrophages and Microglal Cells in Culture with SiV

\begin{tabular}{|c|c|c|c|c|c|c|c|}
\hline $\begin{array}{l}\text { Days of } \\
\text { infection }\end{array}$ & $\begin{array}{c}\mathrm{p} 27 / \mathrm{pg} / \mathrm{ml} \\
\text { (supernatant) }\end{array}$ & $\mathrm{TCID} 50 / \mathrm{ml}$ & $\begin{array}{c}\% \text { of } \\
\text { infected } \\
\text { cells }\end{array}$ & $\begin{array}{l}\text { Days of } \\
\text { infection }\end{array}$ & $\begin{array}{c}\mathrm{p} 27 / \mathrm{pg} / \mathrm{ml} \\
\text { (supernatant) }\end{array}$ & TCID50/ml & $\begin{array}{c}\% \text { of } \\
\text { infected } \\
\text { cells }\end{array}$ \\
\hline \multicolumn{4}{|c|}{ A. SIV $_{\text {mac2s1 }}$ infected macrophages } & \multicolumn{4}{|c|}{ C. SIV moc239 $_{\text {infected macrophages }}$} \\
\hline 3 & 0 & - & - & 3 & 0 & - & - \\
\hline 5 & 0 & - & - & 5 & 0 & - & - \\
\hline 7 & 570 & $10^{\prime}$ & 1 & 7 & 0 & - & - \\
\hline 9 & 3400 & $10^{3}$ & 20 & 9 & 50 & - & 2 \\
\hline 11 & 3700 & $10^{4}$ & 60 & 11 & 100 & - & 10 \\
\hline 13 & 800 & $10^{2}$ & 80 & 13 & 260 & $10^{\prime}$ & 30 \\
\hline 15 & 1000 & $10^{2}$ & 100 & 15 & 2500 & $10^{2}$ & 80 \\
\hline 17 & 417 & $10^{1}$ & 100 & 17 & 850 & $10^{1}$ & 100 \\
\hline 19 & 380 & $10^{1}$ & 100 & 19 & 300 & - & 100 \\
\hline 21 & 510 & $10^{1}$ & 100 & 21 & $B 0$ & - & 100 \\
\hline 23 & 0 & - & $\begin{array}{l}\text { all cells } \\
\text { destroyed }\end{array}$ & 23 & 0 & - & $\begin{array}{l}\text { all cells } \\
\text { destroyed }\end{array}$ \\
\hline 25 & 0 & - & $\begin{array}{l}\text { all cells } \\
\text { destroyed }\end{array}$ & 25 & 0 & - & $\begin{array}{l}\text { all cells } \\
\text { destroyed }\end{array}$ \\
\hline \multicolumn{4}{|c|}{ 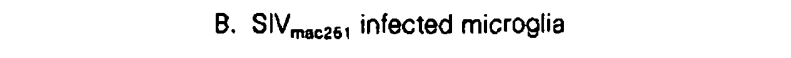 } & \multicolumn{4}{|c|}{ D. SIV mac230 $_{\text {infected microglia }}$} \\
\hline 3 & 15 & - & 1 & 3 & 0 & - & - \\
\hline 5 & 30 & - & 1 & 5 & 17 & - & - \\
\hline 7 & 380 & $10^{\prime}$ & 10 & 7 & 58 & - & 1 \\
\hline 9 & 3850 & $10^{3}$ & 20 & 9 & 250 & - & 1 \\
\hline 11 & 1200 & $10^{2}$ & 20 & 11 & 420 & - & 5 \\
\hline 13 & 510 & $10^{\prime}$ & 20 & 13 & 720 & $10^{\prime}$ & 5 \\
\hline 15 & 490 & $10^{2}$ & 20 & 15 & 3300 & $10^{2}$ & 20 \\
\hline 17 & 110 & 1 & 20 & 17 & 1400 & $10^{\prime}$ & 20 \\
\hline 19 & 90 & 1 & 20 & 19 & 600 & $1^{1}$ & 20 \\
\hline 21 & 90 & - & 20 & 21 & 380 & - & 20 \\
\hline 23 & 0 & - & $\begin{array}{l}\text { Infected cells } \\
\text { destroyed }\end{array}$ & $\begin{array}{l}23 \\
25\end{array}$ & $\begin{array}{r}75 \\
0\end{array}$ & - & $\begin{array}{c}20 \\
\text { Infected cells }\end{array}$ \\
\hline 25 & 0 & 一 & $\begin{array}{l}\text { Infected celis } \\
\text { destroyed }\end{array}$ & & & & destroyed \\
\hline
\end{tabular}

Note. The table represents the data obtained from two independent experiments using cell populations from two uninfected rhesus monkeys.

II expression on almost every cell despite the fact that only $20 \%$ of the cells carried viral antigens. This expression of MHC class II antigen could not be prevented by presence of anti- $\boldsymbol{\gamma}$-IFN in the supernatant and was not induced within 4 days in fresh microglial cultures by transfer of supernatant harvested from infected microglial cells 4 days after infection. For the latter experiments, the kinetics of MHC class II expression by $100 \mathrm{U} / \mathrm{ml}$ human $\gamma$-IFN was used as a control which led to $100 \%$ MHC class II expression in uninfected microglial cells.

\section{Characterization of microglial cells isolated from monkeys infected with SIV mac251 $_{1}$}

CNS tissue was obtained from four monkeys infected with SIV mac251. Animal 1689 was sacrificed at 46 weeks pi (wpi) because of an extranodal B cell lym- phoma of the right orbita, animal 5291 at 20 wpi because of weight loss, apathy and anemia, and animal 5290 at 36 wpi because of weight loss and dyspnea due to an extensive obliterative vasculopathy of the lung. Animal 5029 was clinically silent and sacrificed at 24 wpi according to the experimental schedule. Animal 5291 exhibited full-blown SIV encephalopathy with numerous giant cell nodules distributed throughout the white matter, a giant cell pneumonia, and a generalized lymphoproliferation. The other three animals did not show brain pathology, with the exception of a few small lymphocytic aggregates within the meninges. Microglial cells isolated from these animals started to exhibit cytopathic effects after 25 days in culture, but never to such an extent as seen following in vitro infection. p27 was detected in the supernatant 18-33 days after cell isolation with increasing titers (Fig. 2). At the same time infectious virus of low titer, in the order of 


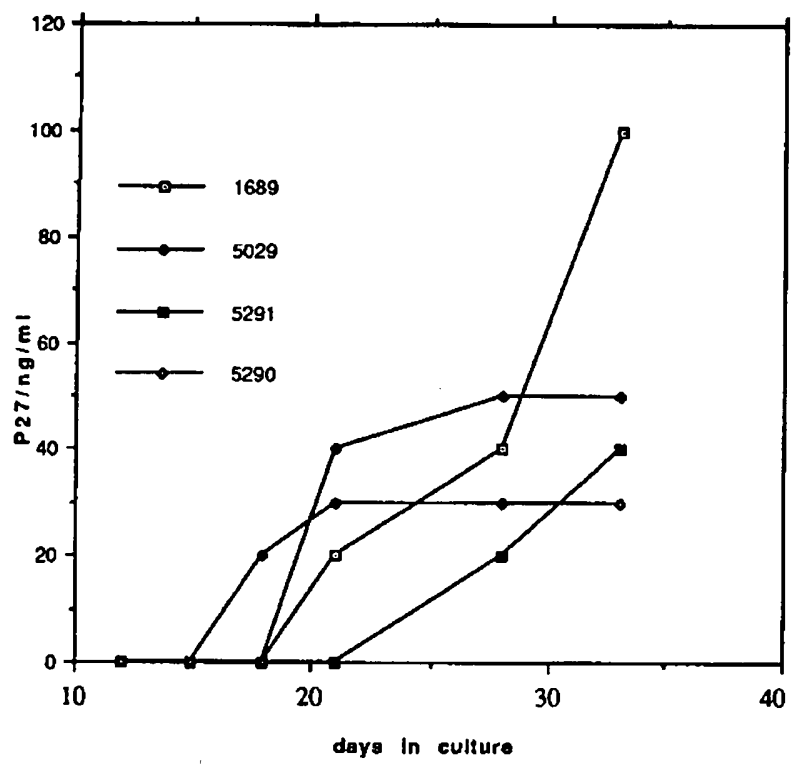

FIG. 2. Detection of p27 antigen in supernatants of microglial cells in culture, isolated from SIV-infected animals. Each curve represents p27 detected in the supernatant of microglial cells of an individual monkey. Each value represents the medium titer obtained from four Costar wells.

$10^{1} \mathrm{TCID} 50 / \mathrm{ml}$, could be isolated from each culture. The percentage of productively infected cells never exceeded 5-10\%. Infected cells could not be detected by immunofluorescent staining before $p 27$ was detectable in the supernatant. Only by in situ hybridization it was possible to demonstrate that about $1 \%$ of microglial cells expressed SIV gag mRNA 10 days after isolation. However, it is of interest to note that all microglial cells expressed MHC class II molecules on their cell membrane at the time of isolation.

\section{DISCUSSION}

In neuro-AIDS there is overwhelming evidence that HIV is present in mononuclear cells, in perivascular microglial and multinucleated microglia, but less evidence of whether ramified microglia are infected (Dickson et al., 1991). In this study we demonstrate that ramified microglial cells from the CNS of adult rhesus monkeys are susceptible to infection by SIV. Nevertheless, in contrast to macrophages only $20 \%$ of microglial cells supported viral replication although no major differences in surface markers between susceptible and non-susceptible microglial cells were detectable. Both resistance and susceptibility of microglial cells to infection with HIV has been reported recently from in vitro studies. Attempts to infect microglial cells from human embryonic brain and spinal cord with two different strains of HIV-1 were without success (Peudenier et al., 1991). No apparent CPE, p24, significant RT ac- tivity, or positive signals by in situ hybridization were noted over an observation period of 21 days. Moreover, addition of uninfected lymphocytes to the infected microglial cell culture or co-cultivation of uninfected microglial cells with HIV infected lymphocytes did not lead to any positive results. In contrast, Jordan et al. (1991) could productively infect primary cultures of adult human brain containing a mixture of microglia and other brain cells with HIV. In these experiments, only macrophage-adapted HIV isolates replicated and induced CPE (Sharpless et al., 1992). The infection of microglial cells was CD4 dependent as demonstrated by blocking antibodies or preincubation of the virus with soluble CD4 (Jordan et al., 1991). At present no conclusive hypothesis is available to explain resistance or susceptibility of microglial cells to retroviral infection in vitro. Probably, as suggested by Dickson et al. (1991) their state of differentiation at the time of isolation from brain tissue is of major importance for viral permissiveness.

The finding that the molecular clone SIV $_{\text {mac239-de- }}$ rived virus infects macrophages and microglial cells as efficiently as uncloned SIV $_{\text {mac251 }}$ is of particular interest since SIV $_{\text {mac239 }}$ has been previously reported to be strictly lymphotropic (Kestler et al., 1990; Desrosiers et al., 1991). However, SIV $_{\text {mac239 }}$ revealed a delay in the occurrence of p27 antigen and reduced levels of cell free infectious virus in tissue culture supernatants compared to the 251 isolate suggesting that macrophage- and lymphotropism of these otherwise closely related viruses is not a matter of receptor binding but of intracellular replication and/or release of mature virions. This is consistent with recent reports revealing that the restricted tropism of SIV $_{\text {mac23g }}$ in macrophages involves post-entry events (Mori et al., 1992). Furthermore, differences in the experimental protocols may explain the conflicting results of our and previous studies. The resistance of macrophages to SIV $_{\text {mac239 }}$ has mainly been established using alveolar macrophages (Desrosiers et al., 1991) which may carry a different susceptibility (Olafsson et al., 1991) compared to the peripheral monocytes we used.

Despite the fact that only $20 \%$ of microglial cells

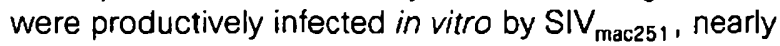
$100 \%$ of cells upregulated expression of MHC class II antigens. For two reasons it is unlikely that the triggering event for MHC class II expression is mediated by soluble factors released by productively infected microglial cells: (1) the presence of high titered anti- $\boldsymbol{\gamma}$ interferon antibody in the tissue culture medium during infection of microglial cells could not prevent the induction of MHC class II and (2) fresh microglial cell cultures could not be induced to upregulate $\mathrm{MHC}$ class II antigens by tissue culture supernatants from microglial cell cultures infected with SIV for four days. Thus, the virus itself may be able to exhibit the stimulat- 
ing event for MHC class II upregulation. This assumption is based on earlier studies from our laboratory showing that viral particles other than HIV or SIV are able to induce MHC class II upregulation on CNS-resident astroglial cells (Massa et al., 1986). The SIV inoculum used to infect microglial cells with an m.o.i. of 1 might contain sufficient antigenic mass to exhibit a stimulatory effect on MHC class II expression. This hypothesis is further substantiated by the absence of a stimulatory effect on $\mathrm{MHC}$ class II expression by tissue culture supernatants taken from SIV-infected microglia $4 \mathrm{dpi}$. Determination of p27 in these supernatants revealed extremely low levels of SIV-specific gag proteins.

Another explanation for the discrepancy between $\mathrm{MHC}$ class II expression and viral infection might be the fact that due to the technology applied we were only able to detect productively infected cells. Of course this does not exclude that almost all microglial cells contain the SIV provirus. In HIV-infected human glial cells the proviral state can be associated by a blocked early stage expression of viral proteins, where mostly the nonstructural protein Nef is produced (Brack-Werner et al., 1992). Maybe this is sufficient to trigger upregulation of MHC molecules in the infected cell. Future experiments will evaluate this possibility by examination of SIV-exposed microglial cells by immunohistology and PCR technology.

Analysis of microglial cells from SIV-infected monkeys disclosed the surprising finding that infectious virus could be recovered from microglia of animals without apparent CNS lesions. Why we did not find differences in virus yield from cells isolated of neuropathological inconspicuous animals and the animal with full blown SIV-encephalopathy is not clear. It is possible that the isolation method excluded multinucleated giant cells due to their different density or fragility. However, in each microglial culture tested the infection was latent and was being activated after 2 to 3 weeks in culture.

Of particular interest is the observation that all isolated microglial cells from SIV infected rhesus monkey at the time of isolation strongly expressed $\mathrm{MHC}$ class II antigen whereas only very few productively infected cells were detectable by in situ hybridization. Upregulation of $\mathrm{MHC}$ class II expression cannot be attributed to a general activation of the microglial cells during the preparation procedure, since it was not detectable on similarly prepared microglia from uninfected monkeys. Thus, MHC class II expression indicates a state of activation that probably is not dependent on productive SIV infection. Similar observations have recently been made in a child with neuro-AIDS (Brinkmann et al., 1992). Isolation of microglia from the brain revealed also a high expression of MHC class II antigens prior to the detection of infected cells. The in vivo findings are in line with the in vitro data showing that upregulation of MHC class II antigens occurs on all cells in the tissue culture after infection with SIV although only $20 \%$ of the cells express viral antigens. However, in contrast to the in vitro data, we cannot exclude that in vivo beside direct viral effects cytokine release by inflammatory $\mathrm{CD}^{+}{ }^{+} \mathrm{T}$ lymphocytes could contribute to this phenomenon.

In conclusion, this study demonstrates that SIV infection in rhesus monkeys is an excellent model to analyze interaction of SIV with brain cells. The similarity of the data with those obtained from HIV-infected patients underlines the usefulness of the monkey model and supports further experiments in the attempt to understand the pathogenesis of neuro-AIDS. This model will allow detailed studies of the aspects of SIV infection in brain tissue that are not accessible in man.

\section{ACKNOWLEDGMENTS}

This study was supported by grants from the Bundesministerium for Forschung und Technologie, Bonn. We thank Helga Kriesinger and Bettina Stein for typing the manuscript.

\section{REFERENCES}

Brack-Werner, R., Kleinschmidt, A., Ludvigsen, A., Mellert, W., Neumann, M., Heramann, R., Khim, M. C., Burny, A., MülleaLANTZSCH, N., and STAVROU, D. (1992). Infection of human brain cells by HIV-1: restricted virus production in chronically infected human glial cell lines. AIDS 6(3), 273-285.

Brinkmann, R., SchwinN, A., Narayan, O., Zink, C., Kreth, H. W., Roggendorf, W., DURRies, R., SCHWENDER, S., IMRICH, H., and TER MEULEN, V. (1992). HIV infection in Microglia: Correlation between cells infected in the brain and cells cultured from infectious brain tissue. Ann. Neurol. 31(4),361-365.

Desrosiers, R. C., Hansen-Moosa, A., Mori, K., Bouvier, D. P., King, N. W., DANIEL, M. D., and RINGLER, D. J. (1991). Macrophage-tropic variants of SIV are associated with specific AIDS-related lesions but are not essential for the development of AIDS. Am. J. Pathol. $139,29-35$

Dickson, D. W., Mattiace, L. A., Kure, K., Hutchins, K., Lyman, W. D., and Brosnan, C. F. (1991). Biology of disease. Microglia in human disease, with an emphasis on acquired immunodeficiency syndrome. Lab. Invest. 64(2), 135-156.

GIULIAN, D., and BAKER, T. J. (1986). Characterisation of ameboid microglia isolated from developing mammalian brain. J. Neurosc. 6, 2163-2178

GYORKEY, F., MELNICK, J. L., and GYORKEY, P. (1987). Human immunodeficiency virus in brain biopsies of patients with AIDS and progressive encephalopathy. J. Infect. Dis. 155, 870-876.

JoRdan, C. A., Watkins, B. A., KufKa, C., and DuboIS-Dalco, $M$. (1991). Infection of brain microglia cells by human immunodeficiency virus type 1 is CD4 dependent. J. Virol. 65(2), 736-742.

Kestler, H. W., Kodama, T., Ringler, D., Marthas, M., Pedersen, N., Lackner, A., Regier, D., Sehgai, P., Daniel, M., King, N., and Desrosiers, R. (1990). Induction of AIDS in thesus monkeys by molecularly cloned simian immunodeficiency virus. Science 248, 1109-1112.

Koyanagi, Y., O'Baian, Wa, Zhao, JQ., Goloe, D. W., Gasson, J. C., and CHEN, I. S. Y. (1988). Cytokines alter production of HIV-1 from primary mononuclear phagocytes. Science 241, 1673-1675.

Lackner, A. A., Smith, M. O., Munn, R. J., Martfeld, D. J., Gar- 
OENER, M. B., MARX, P. A., and DANDEKAR, S. (1991). Localization of simian immunodeficiency virus in the central nervous system of rhesus monkeys. Am. J. Pathol. 139, 609-621.

LETVIN, N. L., and KING. N. N. (1990). Immunologic and Pathologic Manifestations of the Infection of Rhesus Monkeys with Simian Immunodeficiency Virus of Macaques. J. AIDS 3(11), 1023-1040.

MASSA, P. T., DORRIES, R., and TER MEULEN, V. (1986). Viral particles induce la antigen expression on astrocytes. Nature 320, 543546.

MORI, K., RINGLER, D., and DESROSIERS, R. (1992). Restricted replication of SIV mac239 in macrophages is determined by env but is not due to restricted entry. Abstract at the 10th Annual Symposium on Nonhuman Primate Models for AIDS, 17-20 November, 1992 , San Juan, Puerto Rico.

Mori, S., Wolfinbarger, J. B., DOWLING, N., WeI, W., and BloOM, M. E. (1990). Simultaneous identification of viral proteins and nucleic acids in cells infected with Aleutian mink disease parvovirus. Microbial Pathogenesis 9, 243-253.

Olafsson, K., SMITH, M. S., Marshburn, P., Carter, S. G., and HasKILL. S. (1991). Variation of SIV infectibility of macrophages as a funktion of donor, stage of differentiation, and site of origin. J. Acq. Immune Defic. Synd. 4, 154-164.

Peudenier, S., Hery, C., Montagnier, L., and Tardieu, M. (1991). Human Microglial cells: Characterization in cerebral tissue and in primary culture, and study of their susceptebility to HIV-1 infection. Ann. Neurol. 29(2), 152-161.
SEDGWICK, J., SCHWENDER, S., IMRICH, H., DORRIES, R., BUtCHER, G. W., and TER MEULEN, V. (1991). Isolation and direct characterization of resident microglia cells from the normal and inflamed central nervous system. Proc. Natl. Acad. Sci. USA 88, 7438-7442.

Sharpless, N. E., O'Brian, W. A., Verdin, E., Kufta, C. V., Chen, I. Y., and DuBOIs-DALCQ, M. (1992). Human immunodeficiency virus type 1 tropism for brain microglial cells is determined by a region of the env glycoprotein that also controls macrophage tropism. $J$. Virol. 66, 2588-2593.

Stoler, M. H., Eskin. T. A., BenN, S., ANGerer, R. C., and ANGerer, L. M. (1986). Human T-cell lymphotropic virus type-ill infection of the central nervous system-a preliminary in situ analysis. JAMA $265,2360-2364$.

TILLMANN. M., and WIGDAHL, B. (1991). Neuropathogenesis of human immunodeficiency virus infection. "Seminars in the Neurosciences," Vol. 3, pp. 131-140. Saunders, Scientific Publications.

VazeuX, R., Brousse, N., Jarry, A., Henin, D., Marche, C., Vedrenne, C., Mikol, J., Wolff, M., Michon, C., Rozenbaum, W., Bureau, J-F., Montagnier, L., and Brahic, M. (1987). AIDS subacute encephalitis. Identification of HIV-infected cells. Am. J. Pathol. 126(3), 403-410.

Wiley, C. A., Schrier, R. D., Nelson, J. A., LAMpert, P. W., and OLDSTONE, B. A. (1986). Cellular localisation of human immunodeficiency virus infection within the brains of acquired immune deficiency syndrome patients. Proc. Natl. Acad. Sci. USA 83, 70897093. 